\title{
Relative Reliability and the Recognisable Firm Calculating Goodwill Impairment Value
}

\author{
Huikku, Jari; Mouritsen, Jan; Silvola, Hanna
}

Document Version

Accepted author manuscript

Published in:

Accounting, Organizations and Society

DOI:

10.1016/j.aos.2016.03.005

Publication date:

2017

License

CC BY-NC-ND

Citation for published version (APA):

Huikku, J., Mouritsen, J., \& Silvola, H. (2017). Relative Reliability and the Recognisable Firm: Calculating Goodwill Impairment Value. Accounting, Organizations and Society, 56, 68-83.

https://doi.org/10.1016/j.aos.2016.03.005

Link to publication in CBS Research Portal

\section{General rights}

Copyright and moral rights for the publications made accessible in the public portal are retained by the authors and/or other copyright owners and it is a condition of accessing publications that users recognise and abide by the legal requirements associated with these rights.

Take down policy

If you believe that this document breaches copyright please contact us (research.lib@cbs.dk) providing details, and we will remove access to the work immediately and investigate your claim. 


\title{
Relative Reliability and the Recognisable Firm: Calculating Goodwill Impairment Value
}

\author{
Jari Huikku, Jan Mouritsen, and Hanna Silvola
}

Journal article (Post print version)

CITE: Relative Reliability and the Recognisable Firm: Calculating Goodwill Impairment Value. / Huikku, Jari; Mouritsen, Jan; Silvola, Hanna. In: Accounting, Organizations and Society, Vol. 56, 01.2017, p. 68-83.

DOl: 10.1016/j.a0s.2016.03.005

Uploaded to Research@CBS: June २०17

(C) 2017. This manuscript version is made available under the CC-BY-NC-ND 4.0 license http://creativecommons.org/licenses/by-nc-nd/4.0/ 


\section{Relative Reliability and the Recognisable Firm: Calculating Goodwill Impairment Value ${ }^{1}$}

\begin{tabular}{|l|l|l|}
\hline JARI HUIKKU & JAN MOURITSEN & HANNA SILVOLA \\
Assistant Professor & Assistant Professor \\
Aalto University School of & Professor & Copenhagen Business School \\
Business & Aalto University School of \\
Department of Accounting & Management of Operations & Business \\
Runeberginkatu 22-24 & Solbjerg Plads 3, B.5.10 & Runtment of Accounting \\
00100 Helsinki, Finland & 2000 Frederiksberg, Denmark & 00100 Helsinki, Finland \\
Tel.: +358 50 553 1920 & Tel.: +45 3815 2420 & Tel.: +358 50 401 7358 \\
Fax: +358 9 4313 8678 & Fax:+45 3815 2440 & Fax: +358 9 4313 8678 \\
E-mail: jari.huikku@aalto.fi & E-mail: jm.om@cbs.dk & E-mail: hanna.silvola@ aalto.fi \\
\hline
\end{tabular}

\footnotetext{
${ }^{1}$ We appreciate the helpful comments of Christopher Chapman, Seppo Ikäheimo, Juha Kinnunen, Martin Kornberger, Anna-Maija Lantto, Richard Macve, Andrea Mennicken, Anette Mikes, Yuval Millo, Michael Power, Keith Robson, Joni Young, two particularly engaged anonymous reviewers and the editors. We also acknowledge comments from participants of the AOS workshop at the LSE (2011), EAA's Annual Congress in Ljubljana (2012), IPA Conference in Cardiff (2012), and accounting seminars at University of Turku (Turku School of Economics), Aalto University School of Business, Auckland University of Technology, University of Auckland, University of New South Wales, and Macquarie University. Additionally, we want to thank the people interviewed. The financial support granted to Huikku and Silvola by Jenny and Antti Wihuri Foundation, Marcus Wallenberg Foundation, Foundation for Economic Education, and HSE Foundation is acknowledged with gratitude.
} 


\title{
Relative Reliability and the Recognisable Firm: Calculating Goodwill Impairment Value
}

\begin{abstract}
This paper complements financial accounting research by a qualitative study of financial accounting practices. Its object is goodwill impairment tests (IAS 36) under the influence of International Financial Reporting Standards, which it uses to illustrate how financial accounting is produced. The aim is to investigate how accounting standards are translated into accounting practices, and to investigate how this is reliable. Drawing on actor network theory, the paper proposes calculative practices to be a networked and distributed affair. The study has two main contributions. Firstly, it shows that in the case of goodwill impairment tests, financial accounting is a process of finding, qualifying, stabilizing and calculating traces that often have to be found beyond the company infrastructure of sheets of accounts and the financial ledger. Secondly, it shows that these traces increase reliability when they are recognisable and impersonal. No single person is responsible for the financial calculation and the traces used assume that a firm cannot systematically outperform the broader economy or the history of the firm. It also helps to increase reliability if institutional roles such as auditors and valuation experts tolerate the calculation. Reliability increase when traces and supporting institutional actors that take part in the calculation are at a distance. Because of this production process, readers of financial statements face the following paradox: the things they see are less associated with specific entrepreneurial activities in the firm and more with normalised trends inside and outside the firm. Seeing the firm requires them to look at its past, at negotiated budgets, at its competitors, at industrial outlook, and at the statistical bureaus that compile information on the economic development of industries and countries; they may also have to listen to valuation experts and auditors. Seeing the value of a firm requires actors to look elsewhere.
\end{abstract}




\section{INTRODUCTION}

\begin{abstract}
"That's the paradox. That's where we walk a very thin line. We communicate reality: that is the myth; that is what people believe. It is even what most of us believe. And, in a sense, we do communicate reality. There is something there: bricks and people and so on. And the organization can, say, be 'doing well', or 'doing badly', in whatever sense you take that to mean. And it is our job to convey it. But what is 'the full picture'? There is no full picture. We make the picture. That is what gives us our power: people think and act on the basis of that picture! Do you see? Are you beginning to see?" (Hines, 1988, p, 265)
\end{abstract}

Ruth Hines' (1988) famous fable about financial accounting asks of us to contemplate what it is that we see when financial accounting communicates the world. We observe a construction and see less than a full picture, she says: "There is no full picture" (ibid., p. 265). So, which picture does financial accounting make us see? More specifically, when readers of financial statements observe a calculation of goodwill impairment based on net present value, what do they see? To answer this general question, it is necessary to study how financial accountants produce financial statements. While there is a discernible body of market-based research designed to test the effects of financial accounting choices, e.g. in relation to fair value accounting (Laux and Leuz, 2009), empirical research about the production of accounting is largely absent (Durocher and Gendron, 2011; Hopwood, 2000; Young, 2006). ${ }^{2}$ This generally motivates the paper's interest in translations from financial standards into financial accounting practices, which are critical in order to understand what financial accounting makes visible (Robson and Young, 2009).

The paper has two main aims. Firstly, it seeks to explore translations between financial accounting standards and financial accounting practices. As a construction, financial accounting is often presented as easily mouldable because it is mathematical (Vollmer, 2003; 2007) and easy for managers to manipulate by changing the calculation to undertake earnings management (Macintosh, 2006; 2009; Ramanna, 2008). When understood as this type of construction, accounting is in the

\footnotetext{
${ }^{2}$ There are important studies of auditing practices (for an early review of audit practices, see Power (2003), of auditing firms (Anderson-Gough, Grey and Robson, 2001; Cooper, Greenwood, Hinings and Brown, 1998; Gendron, Cooper and Townley, 2007; Kornberger, Justesen and Mouritsen, 2011; Suddaby, Cooper and Greenwood, 2007), and of auditcommittee practices (Gendron and Bédard, 2006; Gendron, Bedard and Gosselin, 2004).
} 
hands of the few who can design it to suit their interests. However, there may be a limit with regard to how far this can go because the more personal financial accounting is the less reliable it will be and then it will not engender trust and comfort (Pentland, 1993; Power, 1995; 1996; 1997; 2003). It is important therefore to investigate whether and how a financial accounting construction is different from a personal statement. The second aim is to explore what readers of financial statements see when financial standards are translated into practices. Accounting standards delimit the financial accounting object in principle, but they do not specify the empirical demarcations that locate the standard in practices of financial accounting (Lezaun, 2006). Financial accounting understands the economic world from the classifications produced by sheets of accounts and the general ledger. They organise transactions and records which are the remaining simple traces from complex economic selling, purchasing and production events. The records in financial accounting database are typically understood as traces of past events. However, International Financial Reporting Standards (IFRS) pose the challenge that financial accounting increasingly is tasked to engage with the future. Traces therefore have to be indications of the future and these traces may not intuitively be part of the set of historical records found in the financial accounting database. It is therefore not clear what it is readers of financial accounting can see when they observe financial accounting.

To achieve these aims, the paper investigates how goodwill impairment is produced. This is a critical case for IFRS because goodwill is a level three asset that requires being tested for impairment by means of models. It has no market value per se (Bougen and Young, 2012; Macintosh, Shearer, Thornton and Welker, 2000). Goodwill is difficult for two reasons. First it is a residual value and has no associated discernible and separable asset; and second it is about the future. It is a critical incidence for IFRS. If goodwill accounting is reliable - in the sense of being able to be relied upon - this may also be so for other IFRS based valuations. Accordingly, the specific research questions are: how do financial accounting practices produce goodwill impairment value, and how is the financial accounting calculation reliable?

Drawing broadly on actor network theory (e.g. Latour, 1989; 1987; 2005), the study examines the practices of calculation as a distributed network. ${ }^{3}$ According to this approach, the preparer is not a

\footnotetext{
${ }^{3}$ Prior research on goodwill accounting has addressed goodwill impairment testing using quantitative methods. This research suggests that impairment testing procedures help opportunistic management discretion in relation to the timing and magnitude of goodwill write-offs (Beatty and Weber, 2006; Massoud and Raiborn, 2003; Ramanna, 2008;
} 
mind or brain that more or less liberally interprets accounting and changes it to suit individuals' interpretations and strategies. Instead, financial accountants are a part of a wider set of actors including both human actors and non-human actants who in their own ways influence the preparation of financial statements. Financial accountants may find themselves in a centre of calculation which is obligated to develop financial statements, but they cannot do this only by themselves. At least, as a centre of calculation, the financial accounting office requires records to calculate on. These records are typically traces of activity that has happened elsewhere in time and space. The financial accounting office cannot calculate if it does not have traces that enable it to translate the financial accounting standard. The financial accounting database is a "large star-shaped web of mediators" (Latour, 2005, p. 217) which allows things to flow into and out of the financial accounting office: traces flow in and financial statements flow out. As Latour (2005) says, any actor such as a financial accounting office is made to exist by many relations and entities. Therefore, the financial accounting office's efforts to develop financial statements are mediated by non-human actants (e.g. traces in the form of records) and human actors (e.g. auditors) that together negotiate what the financial statement is about. Through this approach the preparer is a network more than a single person or mind.

The empirical analysis is based on Finnish data. Finland is a critical case for analysing effects of IFRS on financial accounting practices because IFRS were a radical step for Finnish preparers (Nobes, 2013). Not only did the regulation change from a classical continental European conservative focus to an IFRS fair values approach almost overnight (Erb and Pelger, 2015; Power, 2010), it also made IFRS regulation to be Finnish regulation with no adaptation (Kettunen, 2014). No preparer could be expected to have expertise. ${ }^{4}$ Drawing on interviews with 55 financial accountants, auditors, financial advisors, the financial supervisory authority, financial analysts, investors, creditors, media and practice-influencing academics with a focus on their experiences working with goodwill calculations.

\footnotetext{
Ramanna and Watts, 2012; Wines, Dagwell and Windsor, 2007). New CEOs may use goodwill write-offs to clean the books (Masters-Stout, Costigan and Lovata, 2008), and managers may engage in big bath earnings management and write goodwill off when earnings are already depressed (Jordan, Clark and Vann, 2007).

${ }^{4}$ This makes Finland a critical case for the analysis of the implications of the change of accounting regulation. It is likely that the case of Finland will be a more systematic experiment of the effects of adoption of goodwill impairment testing than Anglo-Saxon countries (Mennicken and Millo, 2012; Nobes, 2013). A few Finnish firms already had a little exposure to goodwill accounting having applied US-GAAP.
} 
The study has two main contributions. As a study of financial accounting in action, it shows firstly that as practice, preparers of financial statements are busy finding, qualifying, stabilizing and calculating traces typically found outside the financial accounting database. The study shows that the traces that are favoured by preparers construct a financial statement, which when observed by readers make them see away from the specifics of the firm.

Secondly, the urge to see away from the firm is an effect of preparers' understanding of reliability. It appears that traces produced by external statistical bureaus, external advisors and consultants are preferred to internal ones; internal traces that are negotiated such as budgets or used for several purposes are preferred to individual and singular ones. Individual traces proposed by entrepreneurial managers are not trusted. This matters because traces are then understood to represent an impersonal "view from nowhere" (Nagel, 1986; Porter, 1992; 1994b). The reliability of the accumulation of traces is helped by many people tolerating it; people who occupy institutionalised positions or roles such as auditors and experts are stronger than financial accountants and managers.

These characteristics make the calculation of goodwill impairment recognisable, realistic and unsurprising. This practice is not as much concerned with seeing the economics of the particular entrepreneurial activities of the firm as may be the ambition of IFRS (Barth, 2007). Instead, drawing on country and industry averages, on historical growth-rates, and on negotiated budgets, the calculation is more average to the firm and the economy than might be expected (see e.g. Ramanna and Watts, 2012). To some extent, the specific properties of the firm disappear from the calculation and what readers of financial statements see when they observe a financial statement is outside the firm either in time (as in historical growth rates) or in space (statistical offices predict macro growth-rates). To observe the firm through financial statements, readers see elsewhere.

The remainder of the paper is organised as follows. The next section discusses a set of theoretical resources that make it possible to study calculation as a process and which draws on actor network theory. Thereafter, the method section is outlined, describing how this qualitative study of financial accounting practices was conducted. The empirical section provides evidence of the process of calculating goodwill impairment value. The discussion makes clear the properties of the calculative practice that produces a goodwill impairment value. Finally, conclusions are provided. 


\section{UNDERSTANDING FINANCIAL ACCOUNTING AS PRACTICE}

Prior studies of financial accounting have focused more on its institutional dimension than on preparers' financial accounting practices (Gendron, Cooper and Townley, 2007; Hines, 1991; Robson, 1991; 2009; Smith-Lacroix, Durocher and Gendron, 2012; Suddaby, Gendron and Lam, 2009). This institutional dimension is, for example, strong in studies about value added accounting (Burchell, Clubb and Hopwood, 1985), inflation accounting (Robson, 1994; Thompson, 1987), and brand accounting (Power, 1992). Such studies emphasise the roles of complex types of politics, claims to expertise, and battles for jurisdiction (Burchell, Clubb, Hopwood, Huges and Nahapiet, 1980). However, the financial accountant seems to be absent. In situations where financial accountants' choices are discussed, the financial accountant is a Weberian ideal type who is a onesided exaggeration rather than an empirical person (Bayou, Reinstein and Williams, 2011; Macintosh, 2006; 2009). Institutional voices are also loud in accounts of IFRS' relationships with processes of financialization and globalisation that connect capitalism, shareholder value, and political economy (Arnold, 2012; Froud, Sukhdev, Leaver and Williams, 2006; McGoun, 1997). Their presence is also felt, albeit in a more general form, in Power's (2010) analysis of the conditions facilitating the rise of fair value accounting (see also Bougen and Young, 2012; Macintosh, Shearer, Thornton and Welker, 2000; McGoun, 1997) and in Hopwood's (1992; 2006; 2009) discussions of the relationships between accounting, economics and finance. To this institutional perspective also belongs research on the role of standard setters in the development of IFRS (Erb and Pelger, 2015).

This body of research focuses on the action of institutions and not much on financial accountants' practices. It is not possible to know how the standard is translated into practice (Robson and Young, 2009 , p. 360). The study of financial accounting practice concerns the work undertaken by financial accountants (Ahrens and Chapman, 2007) when they attend to calculation (Miller, 2001) and quantification (Espeland and Stevens, 2008; Porter, 1992; 1994a). Such work is related to their engagement with the financial accounting database, which is their primary instrument to make financial calculations that communicate and construct the world.

Financial accounting databases consist of records that are traces of economic events: a sales slip, a purchasing note, a production record, a time sheet, a financial payment. The traces create links to events but they are not the events; they are signs of activity that is absent in time and/or space. Instead of storing the sales event and the production event, the traces take their places. Through 
accumulation, traces gradually turn into financial statements (Robson, 1992) or into subsequent financial analysis (Kalthoff, 2005). Since the trace is not the event itself, its only quality is that it is produced according to some procedure - it is an object that is guaranteed by the rules that make it up. This is why it is constitutive more than reflective (Hines, 1988). It is produced by an instrument that guarantees these rules to be followed. A sales event is translated into a trace by an instrument (e.g. by the cash register) that records the revenues of this event and a date (but not the dynamics of the sales activity between a sales person and the customer). Financial accounting is concerned with finding, creating and organising traces that can be accumulated in the financial database (the general ledger and the sheet of accounts). In this way it traces economic events such as sales activities. A trace is a sign that makes something traceable.

This principle can also be found in other areas of social and economic activity. For example, in the case of genetically modified organisms (GMO), traces can be developed which can identify where and when such substances exist by tracing them from laboratory, through production into markets (Lezaun, 2006). Traces are here political objects that entice struggles about proper government because firms, regulators and activists disagree about the appropriate identification of such substances. Therefore the methods for tracing are political rules for identifying substances rather than mere representations of these substances. The so-called "transformation events" are the moments and places where GMOs move from one existence to another, and the struggle is about how the trace is to be made, including whether it is a pure scientific reference or also one which imprints the uses of the GMO. The properties of the trace are thus defined by the techno-legaleconomic properties of the GMO as settled by the administrative instruments that produce the trace. Therefore, the trace takes the place of the GMO rather than describes it.

In another area, such as science, traces are the textual outputs from instruments and which go through accumulation and acceleration to convince sceptical audiences about the claim of a spokesperson (cf. Latour, 1986; 1987). Traces are produced by instruments either in the form of small measurement devices such as thermometer for temperature, ruler for length or watch for time, or by constellations of devices such as whole laboratories. When accumulated, traces turn into inscriptions that move into final academic papers for example in the form of small diagrams. These are the last accumulation and acceleration that the trace goes through. Behind the inscription are traces. Behind traces there are instruments. 
For GMO and science, the trace is part of an administrative process, or an organised procedure, where events are made traceable. The traces are made to show something by a process of accumulation, similar to the process by which nation states attempt to see the country and its population by a process of accumulating statistical traces (Lam, 2011; Miller and Rose, 1990; Rose and Miller, 2008; Scott, 1998). If traces are disturbed, the things to be seen remain ambiguous (Dambrin and Robson, 2011; Rottenburg, 2009). There is a parallel in the case of financial accounting where traces are the records found in financial databases.

This process of tracing is intuitively understandable in the case of conventional, historical accounting with its emphasis on the verifiability of completed events. With regard to IFRS, the event poses a challenge, however, because, as Power (2010, p. 198) suggests, in principle historical cost accounting is substituted by a focus on the future, which implies a "contest between fundamentally different notions of accounting reliability." Reliability in the transaction-based model is concerned with trails of evidence, while for IFRS reliability is related more to investors' reliance on accounting to make investment decisions. Market values would, in principle, be helpful to discover "hidden economic substances" and make them more transparent (Barth, 2007; Bromwich, 2007; Whittington, 2008). This would be a set of financial accounts that the investor could rely upon. The challenge for reliability is that intuitively, the future has not yet made a trace; it is therefore likely that traces are not located in the financial database.

Lezaun (2006) proposes a distinction between delimitation and demarcation to explain how it is possible to develop a procedure for a not-yet-defined event. Delimitation concerns the possibilities of articulating and proposing an object of interest. Demarcation, on the other hand, concerns the practices and instruments used to make the object administratively distinct. For example, IAS 36 proposes that goodwill accounting can be a value-in-use calculation and requires financial accountants to find cash flow forecasts and develop the weighted cost of capital. Demarcation concerns the mechanism by which traces about the empirical world can be organised and made strong enough to pass as appropriate for the net present calculation. In effect, delimitation is the accounting standard and its supporting accounting principles; demarcation is the search for traces that can stand for the future with adequate strength.

The problem is that the future has not yet arrived and therefore it is not obvious which traces can be allowed to stand for it. Hence the research questions: How do financial accounting practices produce goodwill impairment value, and how is the financial accounting calculation reliable? 


\section{THE STUDY}

\section{The standard}

Goodwill has no market value in itself as it is the residual from acquisition value that cannot be allocated to existing material and immaterial asset. IAS 36 requires firms to perform a goodwill impairment test at least annually to ensure that its goodwill is carried at no more than its recoverable value. An impairment loss is the amount by which the carrying value exceeds the recoverable value and is an expense in the income statement. The recoverable value is tested separately in all cash generating units (CGU) and their recoverable amount is the higher of its 'value in use' and 'fair value less costs to sell.' Goodwill can only be impaired; it cannot be reappraised upwardly.

'Value in use' is widely used not only generally (McDonnell, 2005), but also in Finland. This was the only method mentioned by interviewees in the empirical study. It is the present value of the future cash flows from a CGU using a pre-tax discount rate. Estimates of future cash flows have two origins: a period representing 1-5 years based on budgets and strategies, and the growth rate prediction beyond this. According to IAS 36.55, a firm is required to use a pre-tax discount rate that reflects current market assessments of time value of money and risks. ${ }^{5}$

\section{The research}

The empirical material consists of 53 semi-structured interviews with 55 financial accountants (CFOs, financial controllers, financial standard advisers), external valuation experts, the financial supervisory authority, auditors, financial analysts, investors, creditors, media, and academics (see Appendix 1). They were conducted between March 2010 and April 2013 and developed 57 hours of recorded material. Appendix 2 lists the themes of the interviews.

Other empirical evidence includes annual reports and interim reports of the listed companies (especially their notes on goodwill impairment testing), publications and internal surveys of auditing firms, reports produced by FIVA (Financial Supervisory Authority), financial analysts, and

\footnotetext{
${ }^{5}$ IAS 36.57 requires that the discount rate would be the entity's WACC, incremental borrowing rate or market borrowing rate. Estimating WACC requires insight into cost of equity, cost of debt, and target capital structure.
} 
books and blogs written by analysts. In addition, confidential goodwill impairment testing material was revealed to us by some of the companies. Goodwill was important in the interviewees' firms, averaging $57 \%$ of equity. ${ }^{6}$ Generally, for a third of Finnish publicly listed firms, goodwill accounted for more than $50 \%$ of their equity.

In terms of method, interviews were organised around the complexities of the production of goodwill impairment values. Interviewees brought up the idea that calculation is dispersed, and that traces had to be found and made part of the calculation. Questions were related to that translation and focused on challenges posed by goodwill impairment value as both being about the future and about a non-separable asset. These questions concerned the components of the calculation; the process of producing traces relating to cash flows and WACC; the assurance of goodwill impairment values; and participation in the goodwill impairment calculation.

Secondly, the interview data was then organised in themes about the cash flows, the WACC (which were a priori expected to be important), and the process of assurance in and around the audit committee. This latter theme came up as a more important consideration than was first expected.

Thirdly, the thematic organisation around the elements of the calculation of goodwill impairment value was reviewed and lacunae were identified that were then addressed by additional interviews or by returning to interviewees. This, for example, concerned the roles of external experts whose position turned out to be inadequately reflected by the first interviews. Fourthly, the empirical material was then revised in relation to the research questions, and the findings were distilled.

\section{EMPIRICAL OBSERVATIONS OF THE PRODUCTION OF GOODWILL IMPAIRMENT TESTS}

The following empirical account describes how goodwill impairment value is calculated, and in what way it is reliable. The section is organised around the process of calculating goodwill impairment value. IAS 36 delimits the annual impairment test which is to be calculated as the

\footnotetext{
${ }^{6}$ The firms operated in the metal industry, diversified industry, telecommunication/ICT service, the media, chemical and plastics, and the retail trade, and they were listed only in Finland. Financial institutions such as banks and insurance companies were not included in this study. Financial markets are relatively small in Finland: only 124 firms were publicly listed on the Helsinki Stock Exchange during the study.
} 
present value of the future cash flows from a CGU using a pre-tax discount rate. The calculation involves estimations of future cash flows and a discount rate, as financial economics would suggest.

An illustrative example from one of the firms' impairment value calculations is provided in figure 1. This is the product of the financial accounting office, the centre of calculation, which draws together traces from near and far.

--- Insert Figure 1 around here ---

Figure 1 is a delimitation of the object impairment value and it shows the WACC and pre-tax discount rate for each CGU, and then the enterprise value of the CGU is presented next to value on the books. If enterprise value is the higher of the two, no impairment is made. Thereafter, the calculation presents sensitivity analysis for EBIT changes and sales growth changes. Last, there are notes that explain some of its model parameters. The delimitation helps firms to identify relevant traces that make the calculation possible.

This is a delimitation of impairment value, and like Lezaun's (2006) observation about genetically modified organisms it is not obvious how it is possible to demarcate and trace the events that make the delimitation realistic. There has to be some extra work involved in finding the traces of the future that is so strongly present in the delimitation. The following empirical sections are oriented to understanding how demarcation of traces happens in Finland. This involves three steps: first a section on the traces needed to develop cash flow forecasts, thereafter a section on the development of the WACC, and then a final section on assurance by the audit committee.

\section{Demarcating traces to forecast the cash flows}

In the Finnish firms, goodwill impairment testing was part of other pre-existing organisational processes such as budgeting and strategy-making. This would be helpful since goodwill impairment calculations then were not taken "out of the blue", as one auditor (Partner, Audit firm 3) argued:

"It is a completely clear process. And it is, as such, good. It is not an exercise where you just take numbers out of the blue. It is closely related to the budgeting process in the autumn. Goodwill impairment testing is really based on the latest cash flow estimates." 
Being part of a wider procedure added reliability to traces such as budget numbers. There were already traces in the form of past cash flows, and cash flows of the testing year had been defined during the budgeting process. These traces would increase the reliability of the goodwill impairment calculation as they were based on "historical events":

"If we talk about growth of sales volume, we usually start to examine historical events. It gives a base for analyses. If sales volume has increased from two to three percent, and then there is suddenly an estimated growth of 10\%; even dummies can see whether there is any sense. In addition, we need to reflect the figures with economic expectations and forecasts. It is typical for many businesses that the business growth is in line with economic growth plus/ minus something." (CFO, Firm 7)

The traces of "historical events" influenced expectations about growth rates, which would not be reliable if they were abnormal. Even "dummies" would be able to see and recognise this. For a trace to attract reliability it had to have continuity with the past. Erratic movements were understood as noise and traces had to be immediately recognisable or plausible. Reliability would increase if firms' forecasts would follow recognisable, general economic growth rates.

Firms already prepared cash flow forecasts through budgeting for the 1-2 years of the first five years, and the rest were justified by strategy. A CFO explained:

"When we test, we use our established long-term plans, strategic figures. They are there in the background, and we don't make them particularly for this [goodwill impairment testing]." (CFO of Firm 8)

Goodwill impairment tests were organisationally embedded in budgets and in strategic and longterm planning processes. Thus, traces that had several uses beyond the goodwill impairment test would be more reliable than single-purpose traces. Traces were not manufactured only for the purpose of impairment testing but were more generally involved in managing the business; this would strengthen reliability. Single-purpose traces would have too few strings attached and multipurpose traces related to strategy and budgets were organisationally embedded and tolerated by many actors across the organisation. Budgets were compromises between different concerns and this would increase reliability. The CFO of Firm 10 explained: 
"The companies have a tendency to be optimistic in all their planning activities. It inherently belongs to our role as business managers that we think that our improvements and investments lead to good outcomes. In practice, lots of negative issues can happen, which are not integrated into our budgets: competition can become fiercer, raw material costs will increase, and currency exchange rates change surprisingly. Many times we do not take these into account and accordingly the starting point for our numbers is that they integrate positive thinking."

Budget numbers were rarely simple predictions, but negotiated between business divisions (CGUs) and top management. ${ }^{7}$ Business managers often proposed more optimistic ambitions than did top management. It was suggested that "market views are not taken out of the blue, but commonly they include more positive growth than a little bit of pessimism would require" (Financial standard adviser, Firm 4). An alternative was also possible; namely that business management "did not show much confidence in the favourable future development of their business ... the level of ambition has to be much higher" (Auditor 1, Audit firm 1). As a rule, business managers produce "this ordinary story: Namely, those units that are really underperforming want to show too optimistic figures. They want to play for time and avoid being sacked" (CFO, Firm 5). So, budgeting was a process of moderation introduced to make forecasts somewhat more in line with past performance so that the budget would be more recognisable and therefore understood to be more reliable. Top management had to be persuaded, and they typically moderated budgeted growth because the past would, it was presumed, rarely be completely overtaken by new strategies, and the aspirations of ambitious business managers would have to be curtailed by traces of their past which added weight to the reliability of budgets. There was therefore a strong urge to embed budgets organisationally.

This organisational embeddedness was reinforced by the strict boundary that was set between the roles of business managers who produced cash flow forecasts and the financial accountants who put the calculation together in a goodwill impairment value. The CFO of Firm 1 explained as follows:

\footnotetext{
${ }^{7}$ There is a separate concern, too big to discuss systematically here, in devising how many CGUs take part in the cash flow stream: "We discuss continuously what kinds of assets and liabilities should be allocated to this and that CGU. IS there extra cash or something that does not belong to this business? It is a huge job, but very central" (Auditor 1). The design of CGUs can influence how cash flows are taken into account to the point that it can make the difference between impairment or not.
} 
"Business units update business plans [strategy] and provide us with cash flows. After that, testing with the model, determination of the discount rate, everything takes place here [in the financial accounting office]. We do the testing and tell the business units the outcomes. We do not let them do the calculation because we do not want them to play with the figures. So we do it here. Hence, they provide us with only the cash flows, and they should not be able to recognise whether it will lead to impairment or not."

Separation of responsibilities for the different traces of the calculation would also increase reliability because actors would not be able to "play with the figures". This separation and distribution of elements of the calculative practice among calculating actors who would not regularly be in contact with each other would make the resulting financial accounting calculations more impersonal and therefore more reliable (Pentland, 1993; Power, 1996; 2003). The calculation was not the product of any particular individual; it was a procedure that organised and mobilised people from many corners of the firm and beyond:

“The companies I've worked for before hired consultants to devise scenarios for the business concerning the growth rate, changes in the sales prices, or purchase prices as far as the principal raw materials or their main products were concerned. And this, of course, is the best way, as it doesn't represent the viewpoint of the managers, but comes from outside. These are anyway the most important factors, and they are mostly connected with the development of cost or of the sales prices. We have hired consultants in my current company, too." (CFO, Firm 7)

The reliability of the budget would increase if traces "came from the outside" - a "view from nowhere" (Nagel, 1986; Porter, 1992; 1994b). This does not mean that external experts would be better at judging future price and cost; it only means that it was more opportune to allow them to do this. Internally generated forecasts would be understood as subjective and political traces, while external voices, which were at a distance, would be understood to speak more impersonally. They would thus increase the reliability of forecasts.

External traces also took the form of "expectations and forecasts for the whole economy. It is, after all, typical in many business areas that the business grows hand in hand with the economy, give or take a little" (CFO, Firm 7). Traces of the "whole economy" would also make the forecasts more 
reliable as there would be a limit to how different a firm could be from the whole economy; the firm had to have traces that could be recognised from the outside. The CFO of Firm 11 proposed:

"The process of defining the growth rates for terminal value periods is not that demanding. We expect that the growth cannot deviate much from GDP growth. We follow carefully what the other companies use in their disclosures. Additionally, sometimes we have received benchmarking material through our auditors."

The ambition not to stand out too much and to be in line with general developments was proposed as a source of reliability. Estimated growth rates were traced from many and diverse places, many, even most, of which would have external origins that proposed growth not for the individual firm but for the industry or the economy (Vollmer, Mennicken and Preda, 2009). Such impersonal traces were understood to be more reliable than propositions made by individual firms.

Firms' top managers often also preferred external traces because internal budgets were typically of only little assistance with regard to predicting the future, as explained by the CFO of Firm 9:

"You make a calculation in 2005 according to which net sales would be this and that much. When we look backwards in 2008 and the outcome differs, the alarm bells should already ring. Wait a moment! You don't have a clue about the future of your business. It is a good way to make comparisons. We always make it four years backwards. We want to show that our forecasts do not show growth of $10 \%$ and profit improvement of $15 \%$ while the real outcomes are only $2 \%$ and $3 \%$."

Internal budgets were often mistaken and strategy was also much in doubt for the reliability of forecasts:

"There is the problem that it is so easy just to say that you have to forecast your future. Business is required to be forecasted for the next 12 months, which is extremely difficult. These components are so subtle. I haven't seen any strategy that was realised as it was forecasted. By using these figures based on assumptions you will just get some outcome but they are the assumptions you make at that moment. However, there are so many components that they will never be recognised the way they were forecast." (Financial standard adviser, Firm 4) 
IFRS' requirement to calculate goodwill impairment value assumed more certainty about budgets and strategy than firms would normally attribute to them. This is why managers would call the process a "calculative" one:

"It has been very challenging to forecast next year in this sort of a global financial situation [recession]. Well, we forecast our strategy as financial numbers for the next three years but just as she [Financial standard adviser] already said, the terminal value has the greatest impact and how it continues in the future, what is the [terminal] value then..? This illustrates how calculative this testing process is." (Senior Vice President, Financial Control, Firm 4)

This was "calculative", i.e. a simulation, because "terminal value makes about 70 - 80 per cent of an outcome. Whether you have two or five per cent as your growth rate will have a huge influence on the outcome" (Senior Vice President, Finance, Firm 1). Forecasting was important, but managers' experience was that traces such as budgets, strategic plans, and cash flow forecasts would rarely be precise. This is why the process of arriving at cash flow forecasts and growth rates for impairment testing required managers to make the process less personal and therefore less the result of their own guesses. Managers preferred external traces such as industry averages, which would relieve firms from the ambiguous task of budgeting precisely. This was often understood as increasing reliability:

"Once we now have a lot of impairment data, it would be interesting to see if 'industry average' figures will be used some day. It would make the production of these calculations remarkably easier if these industry average values would be generally known. Let's say, for example, that everybody would know how high growth rates in the airlines industry are. That would be a way to get closer to how reliable these calculations are. It would also diminish pressure for accountants to manage these figures because all would know the industry averages. If we differ remarkably from that, we should have a good reason" (Senior Vice President, Finance, Firm 1).

Mobilising traces across and beyond the firm added reliability. The historical past, the multiple uses of budgets, the dampening of optimism, the second opinions of external experts, and the role of industry averages and of country growth rates all contributed to making singular business managers' forecasts more reliable because they were generally recognisable. 
The traces used to propose cash flows could not be found in financial accounting databases but had to be found elsewhere, such as in management accounting budgets (Quagli, 2011; Weißenberger and Angelkort, 2011), or in traces found across organisations, markets and the economy (Vollmer, Mennicken and Preda, 2009). The calculation required by IFRS asked financial accountants to organise others inside and outside the firm so that their traces could be assembled and summarised in the financial accounting office. The cash flow forecast could not rely on readily available traces in the financial accounting infrastructure and these had to be discovered elsewhere. These traces would be more reliable if they were views from nowhere. There was a series of procedures to increase reliability. For example, the budget was relevant for cash flows, but it had to be negotiated and settled between business and top managers before it could be accepted as more than pure subjectivity; two people's compromise would be more reliable. The budget also became more reliable if it were aligned with historical performance since it would not seem plausible if it were possible to outperform history. Likewise, growth rates used for predicting terminal value could be the whims of business managers, but when juxtaposed with external reports about industry or GDP growth they were understood to be more reliable traces for the calculation of goodwill impairments. The further the trace was from the place of the business manager whose entity would produce the work (products and services) that would result in cash flows, the more reliable it was understood to be. The surprising point is that the trace would gain reliability by moving away from the place of business activity.

\section{Demarcating traces to estimate the WACC}

As with the forecast of cash flows, the discount rate - WACC - was also determined as part of the impairment testing process. Companies would use the same WACC for all accounting calculations, e.g. for capital budgeting and for impairment testing, as a CFO (Firm 3) said:

"We test goodwill for impairment once a year if there are no significant events during the year. We use the same WACC figures also in capital budgeting and other [management] calculations."

This procedure dampened controversies around the WACC value and here also the multiple uses of WACC components increased reliability. Many actors, such as auditors, saw WACC determination as both easy and difficult, as explained by an auditor (Partner, Audit firm 1): 
"It is a very difficult issue, or in fact it is on the one hand difficult, but on the other hand easy. You know the components of WACC. They are there, and the major issues are related to the choice of debt maturity - 10 or 30 years - and the capital structure to be used. Will we use the current capital structure or a targeted capital structure set by the board of directors? Additionally, the cost of debt and equity are different in different companies and thus it is difficult to make comparisons between them. Nevertheless, we can compare the development within the company historically. Then we have beta. The problem may be the lack of a reference group for beta values if your company is very unique."

WACC was typically calculated by the financial accounting office, not by business units. Often this would be based on knowledge about other companies via a reference group. Yet, it was also clear that it would be problematic to use such a trace because there would be a "lack of a reference group" because even if there were "a big group of companies we use as a benchmark for determining our WACCs, the problem is that these are companies with different capital structures and financial status" (CFO of Firm 11). The call for a reference group for beta values (riskiness of the firm) was important because they would be the external traces of an item that would be difficult to calculate. There was a preference for external traces: "We sometimes contact financial analysts that analyse our firm or the corporate finance unit of our auditors in order to get benchmarking data for our peer WACC determination” (SVP, Finance of firm 1). The benchmark data was important even if the reference group would be a problem, as mentioned above.

Alternatively, firms could ask for help to check the quality of their own calculations, as the CFO of Firm 5 explained:

"First we discuss in our firm what we think would be a risk-free rate, our capital structure, betas et cetera et cetera. Often we check the components of WACC with an expert. This is not our own auditor, but another auditing firm. We ask them how they see risk premiums in certain circumstances, betas, and risk-free rates. We do not ask directly what our WACC should be. Then we show these [WACCs] to our own auditors. Then they comment on whether it is ok or not. So far it has been ok for them." 
Firms could often calculate the WACC themselves and the external check was frequently a ritual. It confirmed what firms already knew and typically external checks would not change a lot. Yet, it was a useful procedure because this was a way to "play it safe" when there could be controversies about the quality of the traces:

"People widely acknowledge that there are many small firms listed in Finland with less liquid shares. However, people have very different views on how much the beta and other figures of these companies need to be rectified when estimating WACC. Many listed firms buy their WACC estimation from an external consulting firm, because they - the board and the financial management - want to play it safe" (Auditor 2).

The concern to "play it safe" was a result of the traces being ambiguous because estimates of the elements of WACC were based on a more average and industry-wide capital structure and economic outlook in a basket of benchmark companies than those facing the particular firm. This reliance on benchmarks could be even stronger than that which CFOs considered reasonable, because the reference group might be skewed, as a CFO (Firm 11) explained:

"I think that at the moment we have a little bit of a stupid relation between equity and debt in our WACC calculation, but I cannot change it because we have to follow our peer companies. There are financially distressed companies and companies with zero gearing in our peer group. If I try to discuss that I would like to leave this company out, they [auditors and FIVA] say, hey, are you now trying to manipulate the calculation. I say to them, forget it, let's then use the WACC we have now."

While managers were concerned with the firm, auditors were interested in the link to the industry average, which, however, would be an average across very different types of capital structures. The variance between firms was significant. Managers gave up their objections not because they were convinced, but because it was not important enough for them to insist on their views, which auditors understood as manipulation. Here, reliability would increase because managers refrained from objecting as much as they could and allowed auditors' voices to be heard clearly. Criticism towards the use of industry average WACC in the goodwill impairment calculation was presented as follows by a financial standard advisor (Firm 4): 
"In the IFRS approach, WACC should be better linked to the firm in question. If we think about these factors, such as WACC, they should be considered from the business perspective, and not some absolute and overall fair value for markets. It is not possible in reality."

"In reality" it was not possible to produce traces of the firm's capital structure. The WACC calculation was therefore understood to be fragile by managers, and instead of increasing objection to what was considered a dubious procedure, ${ }^{8}$ managers were comforted by others taking the risk. Expert propositions, benchmarks, and quality checks were such risk management mechanisms. This mechanism called on external experts to have a role even if firms believed themselves to be quite capable of producing the goodwill impairment test in-house, as a Senior Vice President, Finance (Firm 1) suggested:

"In my previous firm we used external financial advisors for goodwill impairment testing at the beginning of 2000 to get the expertise. Gradually we strengthened our in-house expertise by recruiting employees from investment bankers to our corporate finance unit and from auditing companies to our accounting department. Accordingly, we no longer have a need to use these external consultants."

At the time of the research, external expertise was not so much used as technical knowledge ${ }^{9}$, as an Auditor (Audit firm1) said: "At the beginning [firms] were seeking expertise about which models to

\footnotetext{
${ }^{8}$ Sometimes managers did object, such as when potential recognition of impairment losses would jeopardise the solidity of the company: "Then it [goodwill impairment loss] strikes of course the equity. You make losses and lose your equity, and this may affect your capacity to pay dividends". (Senior Vice President, Finance, Firm 1); when it affected a company's capacity to pay dividends: "And with regard to this impairment loss, if a company can manage it without a winding up situation, it has an effect on profit distribution. A company may suffer because it cannot pay dividends". (Executive Vice President, Finance, Firm 2); when it triggered covenants: "We have gearing ratio as a covenant: debt versus equity. The debt ratio increases when equity decreases [due to the impairment losses]". (Senior Vice President, Finance, Firm 1). Such effects appear not to have been typical, though, because "When impairment loss is recorded, the market has already earlier discounted it to the value of the company" (Senior Vice President, Financial Control, Firm 4). Managers refrained from strong objections because impairments may not be too surprising. Studies by academics, consulting firms, and the business press suggest that business acquisitions and mergers are more likely to destroy than create shareholder value. It has been reported that about 50-83\% of M\&As fail, which indicates the dilemma that it is difficult to forecast future outcomes of M\&As (de Camara and Renjen, 2004, p. 10; Nguyen and Kleiner, 2003, p. 447).

${ }^{9}$ External experts were in demand at the beginning of IAS 36 implementation, around 2005, when no-one had sufficient knowledge about impairment calculations: For example, a Valuator commented: "At the beginning when these new goodwill testing procedures were introduced, we made much more testing than nowadays ... [now] our expertise is more needed for purchase price allocation [PPA] and acquisition price valuation purposes. If you compare PPA to goodwill impairment testing, very often PPA is made by externals. It is a bit more specific; you need more valuation
} 
use and now ... [they] conduct goodwill impairment testing in-house." It was, in many situations, possible for firms to calculate WACCs, but their own calculations would be understood as lacking reliability. When external sounding boards and experts tolerated it, it became more reliable.

As with cash flow forecasts, WACC also required distribution. To make traces more reliable, firms had to "play it safe." Playing it safe was a strategy for sharing the risk of judgments involved in the calculation, e.g. of beta values. External experts were not only there for their separate expertise (Gendron, Cooper and Townley, 2007; Power, 1995; Smith-Lacroix, Durocher and Gendron, 2012). They were also there to engage an unsolvable conundrum - "in reality," as it was articulated, it was difficult to imagine a calculation that would take the firm's situation into account and not primarily be a calculation of the average market. External valuation experts were called upon to handle the conflict between auditors and managers - the conflict between recognisability and business sense. Their solution was built on their tables of betas and their judgment, but these only resolved the problem of reliability and not the problem of the business sense. Their solution fell on the side of recognisability where the firm would be understood to be an example of the wider industry, while managers retracted and decided that their objection was not serious enough to suffer the consequences of attacks by auditors and regulatory authorities.

\section{Assuring the calculation}

The audit committee had to be convinced of the calculation. It tested goodwill impairment values, or their relative reliability, by interrogating auditors and the CFO (Gendron and Bédard, 2006; Gendron, Bédard and Gosselin, 2004). The test of the goodwill impairment test was comprehensive, as an auditor (Partner, Audit firm 1) described:

"We have some fundamental issues to analyse. Are they really committed to their business plan, are the goodwill impairment figures related to it? What happens in the business environment? Comparison to the previous years will be made. We do mechanical testing using our own calculation models and compare, for example, whether we have the same WACC. We do sensitivity analysis and compare with their analysis. We check all the components. How realistic and likely they are. Additionally,

expertise on intangible assets. It is not something that the in-house team does every day" (Valuator 1, Managing Director of a major international financial advisory firm). 
we discuss with corporate management about the basic assumptions in the testing. And last but not least, we add up all the units [CGUs] and check whether the firm value generated by this exercise correlates with the market value. I am also present at all the meetings of the audit committees."

Auditors checked traces and calculations and carried out sensitivity analysis. In a sense they repeated financial accountants' procedures to arrive at the impairment value, not just taking the effort to calculate but also to review strategies and budgets. It was, as suggested, analysis of "fundamental issues" and auditors introduced these to the audit committee. This was the place where everything came together for the second time (after the financial accounting office) and was tested for reliability. This was where, as Auditor 1 said:

"We have very detailed discussions [in the audit committee], what we have done, what we have noticed in the calculations, which kinds of issues are sensitive and have to be followed carefully, and also we go through the quality and completeness of the disclosures.”

The "detailed discussions" produced a concern with the "quality and completeness" of financial accounting and its reputation was at stake. The financial accounting office had to be able to stand trial for its undertakings.

Auditors were prepared for audit committee meetings. Before the meetings, they checked traces and made reasonableness tests. They went through the strategy documents and related this to sensitivity analysis and the firm's market value. The process of convincing the audit committee would be "very, very serious" as the CFO of Firm 5 said:

"To somehow illustrate the significance of goodwill, you can have a look at these 25 pages of analysis about goodwill impairment testing that we have gone through with our audit committee. Discussing this material will take about $60 \%$ of the meeting time. This is very, very, serious... As I already told you, our auditor has said that if there is something he must audit, it is definitely the goodwill value. And when he has done this, he sleeps well. Of course they check other issues, too, but this is very important." 
These 25 pages of analysis were indications that care had been taken to review the impairment value. The efforts developed to review the calculation were often about the past, historical traces, as explained by Auditor 4:

"Especially important is to go through the historical development; how precise are the forecasts they [firms] have done in the past and what have been the real outcomes of these forecasts; whether there are variances or not. It is very fundamental to look at this even at an annual level and see how the estimations of the previous year and the result of impairment testing fit with the actual outcome. Historical success and failure in this process are indications of the capability of the firm's management to show whether they are able to keep their promises or not. This is the first step in auditing goodwill impairment tests.”

Auditors reviewed managers' and financial accountants' ability to keep their promises about the future. This post hoc evaluation was a test of forecast accuracy. The step was to test documents against documents - traces against traces - and hardly the business per se. Therefore, they checked less whether forecasts were reasonable, whether the terminal value was reasonable, or whether the WACC was reasonable, because these were business concerns. They checked more whether, when put together, the impairment value followed rules (Pentland, 1993; Power, 1997). In this sense the calculation was distributed; it summed up calculations made elsewhere, as explained by Auditor 4 (Audit firm 4):

"The auditing of goodwill impairment testing is very detailed. We follow ISA $540^{10}$. Internally we use our corporate finance guys for valuation purposes. We ensure that the calculations are mathematically correct by using our own calculation models. We benchmark and analyse the WACC parameters. We consult the industry experts to understand market views. We check whether it is true when the firm says that the market will start to improve: How it is related to the available data about the markets? I can say that this testing is taken very carefully and seriously."

The auditors' role in goodwill accounting was to review the firm's strategy by testing whether "managers are committed to their budgets and [cash flow] forecasts, and that these figures are

\footnotetext{
${ }^{10}$ International standard on auditing: Auditing accounting estimates, including fair value accounting estimates, and related disclosures.
} 
linked with the goodwill impairment calculations ... we check whether we have the same WACC ... from external sources ... and then check with market values" (Auditor 1, Audit firm 1). Auditors checked the process, e.g. via additional non-human devices such as the ISA $540 .{ }^{11}$ They focussed on checking the mechanics of the calculation and asked external experts, consultants and advisors to provide the business inputs for the calculation. Auditors assessed the consistency of the narrative and the mathematical correctness of the calculation. Auditors knew that they faced the risk "that somebody will come and say, hey, this impairment loss recognition should have been booked two years ago" (Director of corporate finance, Audit firm 1), but "in practice, auditors cannot challenge future cash flows. The figures are according to the plans that have been approved by our board of directors" (Senior Vice President of Financial Control, Firm 4). Therefore, the role of auditors could not be to go beyond the traces of cash flows because these had been negotiated elsewhere.

Auditors recounted financial accountants' work and evaluated its "completeness and quality." Yet, it was not a place where auditors felt quite at home because they had reservations about numbers with regard to the future; such numbers created discomfort (Justesen and Skærbæk, 2005):

"For us auditors this is really difficult. We are not allowed to say that they [cash flow forecasts and WACC] are guesses; they are estimates. We are talking about future estimates. It is not an exact science at all. Everything is based on judgments and estimates and for us it is extremely difficult to say what the right figures would be" (Partner, auditor; Audit Firm 3).

Such discomfort with numbers was present even if all traces were checked. There was still doubt:

"In the audit committee the CFO presents the [goodwill impairment testing] calculations. The members ask questions and try to figure out the quality of the testing. I am also present there. I say what we have done, and sometimes I have to explain to them more what this testing is about. Sometimes the members want to hear

\footnotetext{
${ }^{11}$ This intensive checking of calculation of value in use was super-checked by the Finnish Financial Supervisory Authority (FIVA). Annually, FIVA checked listed firms with high goodwill compared to their equity, and selected other firms for random checks. If calculations were not satisfactory, FIVA would give a list of requirements to be implemented for the subsequent year. In this way FIVA influenced the emergence of a set of recommended practices for a goodwill impairment testing process generally, and the determination of WACC specifically. In other words, even though FIVA emerged after the publication of numbers, their scrutiny would influence future procedures. This was understood to improve reliability.
} 
the comments about the testing from the auditor in order to ensure that the CFO and the auditor tell the same story" (Auditor 2, Audit firm 2).

Auditors' doubts gave them two tasks in the audit committee. One was to show the process - to recount financial accountants' work - including having "to say what the testing is all about" which was not obvious to audit committee members. Their work was subtle and evasive. Another task was to develop a narrative that the CFO, the auditor, and the audit committee could agree upon. Since there was a limit as to how precise the auditor could be, the task was also to assure agreement about a story. Not even auditors could see through all the numbers because these were about the future.

The assurance of the impairment value repeated the financial accounting process. In many ways, it was a mirror activity to the financial accounting activity. Both processes were oriented towards finding, qualifying, stabilizing and calculating traces. Both processes were oriented towards increasing reliability by increasing traces, by assembling many people and by trusting traces with multiple purposes. Managers, auditors, external experts and financial accountants refrained, however, from excessively strong statements about the future. ${ }^{12}$ Instead, they placed traces in the form of benchmarks, industry reports, and economic forecasts to propose growth rates and WACC elements; they also returned to the history of the firms, the business units, and the CGUs to allow traces about the past to frame the future.

Yet, this reliability was relative and not absolute. Actors were still worried because the future was still a problem irrespective of all the checking and all the composition of the traces. Auditors worried that they would not know enough about the business. Managers worried that not enough of the business would be present in the calculation. External experts worried about their role to assure numbers that managers did not quite believe in, and financial accountants worried that they had not been able to reach far enough in their discovery of traces. The audit committee worried whether it could develop a narrative that would explain to inquisitive others that goodwill was not a feeble asset such as a 'goodwill bomb' as journalists often claimed. All this worrying indicates that reliability was relative. Reliability was not absolute because if such were the case this would efface

\footnotetext{
${ }^{12}$ Research has noted that net present value calculations are only parts, and sometimes even small parts, of the justification of strategic investments in firms; other strategic qualities and organisational politics play important roles (Arnold and Hatzopoulos, 2000; Bower, 1970; Brunzell, Liljeblom and Vaihekoski, 2013; Miller and O'Leary 1997, 2005a, 2005b, 2007). This poses a problem for goodwill impairment accounting where net present value calculations are assumed to be strong.
} 
worry. Reliability was relative and the goal of the audit committee was to agree on a narrative that was (hoped to be) reliable enough to be tolerable.

\section{RELATIVELY RELIABLE AND RECOGNISABLE IFRS NUMBERS: GOODWILL IMPAIRMENT TESTING AND CALCULATION AS PROCESS}

This study investigates the practice of calculating goodwill impairment value that is reliable enough. The detailed analysis of a calculative practice - the goodwill impairment value calculation - illustrates that a calculation develops by finding, qualifying, stabilizing and calculating traces. This calculation carries with it a large array of human actors and non-human traces that take part in its realisation and make it reliable enough. Reliability is never categorically present/non-present; there are always hiccups, disbeliefs, shortcuts and disagreements that are not comforting, yet are tolerable. Therefore, reliability is relative.

\section{Seeing value requires looking elsewhere}

Goodwill impairment value is the result of a calculative practice that is organised by financial accountants who find, develop and mobilise traces that are made by many hands, minds and tools within and beyond organisations. This is a process that turns traces into financial statements through calculation. Here, goodwill is a particularly difficult asset because it is a non-separable asset that requires net present value calculation. While Barker and Schulte (in press) suggest that it is, in principle, impossible to carry out impairment tests because there are no institutions in support of it, the present study suggests a possible way out of this problem by focusing less on institutions and more on the practices of calculating. This practice makes the task of calculating a financial number less oriented towards the mathematical operations on traces (Vollmer, 2003; Vollmer, 2007) since there is a requirement of a net present value calculation as delimited by IAS 36 . The practice is more concerned with identifying and organising traces that have to be discovered in and selected from various places across time and space within and beyond the firm.

The mathematics of calculation - how to make the world visible - is a minor concern because it has already been defined by regulation. IAS 36 develops a delimitation - a template of a financial model - which is not easily given up as it is mandated. The drift noted for example by Quattrone 
and Hopper (2001; 2005), requires that accounting is understood as malleable, seems not to be as urgent in the case of goodwill accounting where the delimitation is clearer.

The delimitation defined by IAS 36 gives financial accountants a task which is to find and support a single authoritative statement about financial value. There seems to be more controversy about demarcation concerning the selection of traces that make it possible to end up in a calculation that is reliable enough. As the study shows, this concern turns financial accountants into discoverers of traces more than calculators on traces. Their task is to search for traces that add reliability which leads them to search further away. Distance matters; at the distance are traces which are not tainted by the hands of financial accountants and managers. As effect, when readers use financial statements to see the firm they look at traces about other things inside or outside the firm than its entrepreneurial activities themselves. Accounts of entrepreneurial activities are too singular and idiosyncratic to be recognised as reliable because such traces are understood as personal. To ascertain reliability, the study shows, calculative practices draw together traces from within and beyond a firm's financial accounting database (Vollmer, Mennicken and Preda, 2009), it is a mechanical production process (Pentland, 1993; Power, 2003), it arranges a plethora of different traces and cascading devices ( $\mathrm{Qu}$ and Cooper, 2011), and by that process it operates a fluid infrastructure rather than a stable one (Lezaun, 2006). Each of these traces increases reliability because they are understood as recognisable by readers. They are understood as not manufactured for a particular calculative episode.

This is a strangely cumbersome process because financial accountants are quite capable of performing the calculation themselves. They know all the aspects of the calculation because they manage the delimitation that is used to find, qualify, stabilise and calculate traces. The problem is that even if they do master the process, their own calculation is subjective. Financial accountants would be understood as speaking on their own (or their managers') behalf rather than providing an impersonal (Porter, 1995) view from nowhere (Nagel, 1986; Latour, 1987). To increase their ability to speak for the many, financial accountants design strategies to increase reliability. Generally, such strategies decentre individuals and substitute them for traces that extend well beyond the firm's financial database to industry outlook, benchmark numbers, national GDP projections; and they extend into human expertise such as institutionalised expert positions and auditors' reviews. No one carries the whole calculation - it is distributed much wider than the financial accounting office and many attempt to influence it within and beyond the firm. 
Reliability is related to the recognisability of the traces and to the impersonality of the calculation. The three mechanisms already mentioned (increasing number of external traces; increasing the number of human allies; increasing multi-uses of traces) make reliability stronger. This explains the paradox that external experts can be necessary and superfluous at the same time, and that managers may not be willing to insist on what they believe to be business sense but auditors would believe to be manipulation. This happens, for example, when financial accountants accept a WACC that might have been more appropriate if the firm's actual capital structure had been taken into account, rather than the average capital structure reported in benchmark reports. It also happens when ambitious business managers accept that they do not follow their idiosyncratic growth aspirations related to their entrepreneurial activities but rather follow industry-wide historical growth-rates.

This is where firms, by giving up their preferred WACCs and growth-rates, substitute their views with those of external experts and auditors. They may not believe experts' views but they can maintain that they are at least not personal and therefore not subjective. This also explains why calculative practices such as financial accounting are less liberal than other accounts that emphasise people's personal power to transform them largely at will (Kalthoff, 2005; Quattrone and Hopper, 2005; Vollmer, 2007). It also explains why the goodwill calculation may not be stabilised by an infrastructure of referentiality which would provide a "singular and unambiguous referent" (Lezaun, 2006, p. 499). Financial accounting practices, as described above, negotiate frictions due to concerns about recognisability and impersonality. This is a social activity rather than a personal one. Therefore, as a centre of calculation, the financial accounting office is a site that invites and assembles actors; it is not mainly a cognitive mind or primarily an interpretive process (Hines, 1988; McKernan, 2007). Nor does it operate an unambiguous bureaucratic referent, because financial accountants and others worry all the time about where a new proposed trace may come from. The referent is an obligation or a task for financial accountants who consider it ambiguous and frail.

Actors face the problem that they would like to be able to recognise - i.e. create the ability to see economic events, but this creates the following paradox: the things people see when they observe financial accounting are associated less with the firm's entrepreneurial activities and more with things outside the firm. They imagine that seeing the firm requires them to look at its past, at its competitors, at industrial outlook, and at the statistical bureaus that compile information on the economic development of industries and countries; they may also have to listen to valuation experts 
and auditors. Seeing the firm requires actors to look elsewhere. This paradox makes the firm's calculation much more average than it would be expected given the promises of IFRS. These would most likely imply a much more differentiated and singular notion of the individual firm' entrepreneurial activities (Barth, 2007; Bromwich, 2007; Whittington, 2008). For market-based research, which cannot find singularity, this is a conundrum (Ramanna and Watts, 2012); for a network perspective on calculative practices it is understandable.

This average is not necessarily conservative in an accounting sense, however, because it relies on general economic outlooks and prospects. Such traces can be more aggressive than historical traces found in a particular firm because the economy may be proposed to turn from slow growth to high growth. Average growth-rates therefore may not be conservative. This is also clear when top managers insist that divisional managers are too reluctant to commit to growth to anticipate accountability. So, reliability is not similar to conservatism even if it produces the tendency towards the average growth rates for a firm, an industry, or a nation.

\section{The proliferation of calculating agencies}

When they draw things together, financial accountants compose a large network of human actors and non-human traces. While financial accountants occupy a position as a centre of calculation, the list of allies that help to prepare the financial statement is much larger. Preparers are not even restricted to within the firm, but have positions across time and space. They are all those human actors and non-human traces developed by calculating agencies beyond the firm that help financial accountants make the goodwill calculation more reliable.

The study shows that there are many other calculating agencies other than the financial accounting office (Czarniawska, 2004). These other agencies are scattered within and outside the firm such as managers' negotiation of budgets, statistical bureaus and consulting firms who all produce calculations. The financial accounting office is a centre of calculation for the impairment test, which the other calculating agencies are not; it draws together other calculating agencies' calculations. This is also partly what the Road Map (Miller and O'Leary, 2007) does when it arranges firms in relation to investments in technology and then develops acts of coordination. The financial template does not intervene on the other calculating agencies as the Road Map does, though, because the financial template only requires other calculating agencies' calculation and not their subsequent acceptance. The financial accounting office moves things (such as calculations) into the firm and 
summarises this in one number; the Road Map moves things (such as commitment to invest) out of the firm into several instances of autonomous decision-making.

Other calculating agencies add degrees of reliability because their calculations are not seen as personal accounts. Particularly in relation to IFRS, traces become a concern because of the requirement to calculate a future-oriented net present value for a non-separable asset. This asset may be identified by the financial infrastructure but its value is not defined by it. This requires attention to the details of finding traces, of qualifying traces, of stabilising traces and of calculating them, which may be more cumbersome than most extant research reveals. There is a significant burden in the production of traces, which indicates that even if it is possible to make calculation a malleable practice, there is a continuing worry about what the trace can help to explain. For example, Dambrin and Robson (2011) point out that in some instances it may be impossible to follow through and find the origin of traces. Likewise, Frandsen (2009) illuminates the difficulties encountered in tracing the translations between medical treatments and financial numbers, and Preston (2006) shows that when calculations are put to work they disregard many aspects of the world that may return and haunt the effects of the calculation. Therefore, the traces are possibly weaker than imagined by actors. There is a limit with regard to how much can be known about what they retain because the principles of recording and calculating can both be multiple and difficult to monitor (see also Nobes, 2013; Nobes and Stadler, 2013). Many traces lack their own history and are guaranteed primarily by the reputation of their calculating agencies (e.g. institutions such as valuation experts and auditors, statistical bureaus and industrial association, and government agencies) rather than by specific knowledge about their characteristics and qualities, and therefore the only promise is that they have been produced by a procedure even if this procedure may itself be dimly lit or foggy. Sometimes it may be a source of objection such as when managers and auditors disagree on what to take into account: recognisability or business sense. Therefore, the calculations performed on top of such traces may seem to be much clearer and more powerful than the traces would justify by themselves.

In effect, the calculation (of goodwill) brings the firm into existence and makes it visible in a peculiar way (Hines, 1988; Kalthoff, 2005). The orientation towards the future which IFRS obligate financial accountants to take into account brings to them a challenge to justify the future reasonably reliably. As the future cannot be known the obligation to account for it is not trivial. The obligation to account for the future harbours the demise of the calculation because the future will probably be 
different from the calculation's predictions. Therefore, the productive power of the calculation is ambiguous. It brings the firm into existence in a form that most people do not believe strongly.

Financial accountants produce an ambiguous calculation but they share the burden of reliability with many other calculating agencies. Other agencies develop calculations which are taken as input to the financial accounting office's work. Agencies such as statistical bureaus, industry organisations, consulting firms with valuation expertise, government agencies and international organisations such as EU and OECD all produce calculations of growth rates, beta-values and interest rates. These agencies all produce calculations and since these calculations are not produced for the purpose of the individual firm's impairment test, they are understood as impersonal. When the financial office invites remote calculating agencies into its own calculative work, it makes many agencies carry the burden of reliability. Financial accountants organise a process but this is not only or primarily a process of adding, subtracting, multiplying and dividing numbers (Vollmer, 2003; 2007) which is largely defined by the delimitation of IAS 36. It is more importantly a process of demarcation by identifying the traces and their associated calculating agencies which are hoped to be recognised by readers as having enough reliability.

The study thus shows that reliability is relative. It is not relative to the world as such; it is relative to degrees of recognisability and impersonality via the work to find, qualify, stabilise and calculate traces. This work takes time and effort, and is never final.

\section{CONCLUSIONS}

This paper reports a qualitative study of financial accounting in the area of goodwill impairment testing. Specifically, the study investigates how a calculative practice produces goodwill impairment value, and how the calculation is reliable. The study discusses the calculative practice involved in producing goodwill impairment values that are recognisable and impersonal enough to pass the test of reliability. 
It contributes and adds to the literature by firstly providing a qualitative study of financial accounting practices, which is rare in the literature. ${ }^{13}$ It shows that the financial accounting calculation (under the influence of IFRS) is a distributed affair. The list of traces that help in the preparation of financial accounts is much larger than the financial accounting office, and even the firm. This list includes human actors and non-human traces from beyond the firm. Secondly, it contributes by showing how reliability is relative. It is relative not to the world but to the degree of recognisability and impersonality of traces.

Such a relative view on reliability is important vis-a-vis studies of quantification that lead to institutionalised infrastructures of referentiality (Lam, 2011; Espeland and Stevens, 2008; Porter, 1995). Even highly institutionalised infrastructures, such as sheets of accounts and general ledgers, have their ambiguities. These infrastructures are leaky (Callon and Latour, 1981) because in spite of commensuration and institutionalisation (Espeland and Stevens, 1998) they are not comforting for practicing financial accountants. Through IFRS, fair market value is connected with the financial accounting database in the sense that the general ledger makes room for the item goodwill, but its value is found elsewhere. It is not possible to demarcate clearly the possible entities that can speak for a (future) market. The financial accountant cannot know where to look for the future because it can be claimed by many different traces. The structure of the calculation (delimitation) may be stable but the set of traces (demarcation) that can or does make it up is potentially endless. With IFRS the uncertainty about the boundaries of the calculation has increased.

IFRS create two challenges for financial accounting. The first challenge is that IFRS have created a leak in the financial accounting database. It is less authoritative than before, when it was a strong(er) infrastructure of referentiality (Lezaun, 2006) and, now, its institutionalised power is reduced because it only develops a space for an asset but not its value. The second challenge is that uncertainty has been produced as to who creates the calculation. The calculation is made from a heterogeneous network of people and traces. This network cannot be restricted by the delimitation of an infrastructure. There are human actors and non-human traces, each of which can challenge the infrastructure and the calculation (of goodwill), such as new reports from various calculating

\footnotetext{
${ }^{13}$ This is one qualitative study of financial accounting and more studies of this kind are useful. The study has shown the general complexity of calculation, but since the empirical evidence is developed from many different companies and sites, it is relevant to study, as case studies, parallel processes within particular firms. This would add insight to the differences between situations and not least more insight to the relations between financial accounting and broader organisational processes of planning, strategizing, and management accounting.
} 
agencies from governments or industrial associations through international organisations and statistical bureaus that paint pictures of future growth rates, and differences in 'subjectivity' between managers, top managers, auditors and experts. These concerns may be part of the heterogeneous calculating network, but they are hardly delimited members of the infrastructure. Even when the calculation is stable (such as the goodwill impairment calculation) there is potential for endless numbers of traces each of which can be opened and new traces will be found. Nobody knows what a calculation of goodwill impairment contains before it is challenged. If unchallenged it is a black box that functions cleanly; when challenged, for example in relation to recognisability and impersonality, new traces can become important. The effect of this is that reliability of a calculation and its traces is relative.

Considering Robson and Young's (2009, p. 360) suggestion that "studies of the performativity of new standards and accounting calculations may help develop further insights into the construction and reconstruction of accounting and economic agency," this study of the goodwill impairment calculation shows the task facing practicing financial accountants. They have to produce calculations that bring things into existence. A goodwill impairment calculation may be an extreme case because goodwill is a residual, non-separable asset. This illustrates that the work produced by financial accounting is not to represent the world; it is to substitute the world with a calculation that is recognisable and impersonal.

Preparers of financial statements may not be able to see the future but they can have a look at budgets, predictions, experts' opinions etc. These traces exist. These traces suggest that something does happen and that this something seems to have substance. Precisely what this something is, however, is ambiguous. At least it is ironic that in order to see the firm - or its goodwill - people have to look elsewhere around and beyond the firm. It is also ironic that the traces that thus attract attention are those that have become normalised so that the firm becomes an instance of wider processes taking place in an industry or in the economy. The result is an average firm - an average goodwill impairment value. This may not have been the intention behind IFRS as it would expect singular values for singular firms (Barth, 2007; Bromwich, 2007; Whittington, 2008).

The present study of the goodwill impairment calculation has begun to illustrate some of the concerns that face financial accountants. Financial accountants are collectors, producers and managers of traces. At every corner they can expect, but not necessarily experience, traces that are 
ascribed even more recognisability and impersonality. Relative reliability makes the possibility of new traces a continuing worry.

\section{REFERENCES}

Ahrens, T. and Chapman, C. S. (2007). Management accounting as practice. Accounting, Organizations and Society, 32 (1-2), 1-27.

Anderson-Gough, F., Grey, C. and Robson, K. (2001). Tests of time: organizational time-reckoning and the making of accountants in two multi-national accounting firms. Accounting, Organizations and Society, 26(2), 99-122.

Arnold, P. J. (2012). The political economy of financial harmonization: The East Asian financial crisis and the rise of international accounting standards. Accounting, Organizations and Society, 37(6), 361-381.

Arnold, G.C. and Hatzopoulos, P.D. (2000). The Theory-Practice Gap in Capital Budgeting: Evidence from the United Kingdom. Journal of Business Finance and Accounting, 25(5/6), 603-626.

Barker, R. and Schulte, S. Representing the market perspective: Fair value measurement for nonfinancial assets. Accounting, Organizations and Society, in press.

Barth, M. E. (2007). Standard-setters, measurement issues, and the relevance of research. Accounting and Business Research, 37(3), 7-15.

Barwise, P., Higson, C., Likierman, A. and Marsh, P. (1989). Accounting for Brands. London: London Business School/ICAEW.

Bayou, M.E., Reinstein, A. and Williams, P.F. (2011). To tell the truth: A discussion of issues concerning truth and ethics in accounting. Accounting, Organizations and Society, 36(2), 109-124.

Beatty, A. and Weber, J. (2006). Accounting discretion in Fair Value Estimate: An Examination of SFAS 142 Goodwill Impairments. Journal of Accounting Research 44(2), 257-288.

Bougen, P. D. and Young, J. J. (2012). Fair value accounting: Simulacra and simulation. Critical Perspectives on Accounting, 23(4-5), 390-402. 
Bower J. (1970). Managing the resource allocation process. Boston, MA: Harvard Business School.

Bromwich, M. (2007). Fair values, imaginary prices and mystical markets, in P. Walton (Ed.), The Routledge Companion to Fair Value and Financial Reporting. London: Routledge, 46-68.

Brunzell, T., Liljeblom, E. and Vaihekoski, M. (2013). Determinants of capital budgeting methods and hurdle rates in Nordic firms. Accounting and Finance, 53(1), 85-110.

Burchell, S., Clubb, C. and Hopwood, A. G. (1985). Accounting in its social context: Towards a history of value added in the United Kingdom. Accounting, Organizations and Society, 10(4), 381413.

Burchell, S., Clubb, C., Hopwood, A. G., Huges, J. and Nahapiet, J. (1980). The roles of accounting in organizations and society. Accounting, Organizations and Society, 5(1), 1-25.

Busco, C., Quattrone, P. and Riccaboni, A. (2009). Management Accounting. Issues in interpreting its nature and change. Management Accounting Research, 18, 125-149.

Callon M, and Latour B. (1981). Unscrewing the big Leviathan: how actors macro-structure reality and sociologists help them to do so. In K. Knorr-Cetina and A.V. Cicourel (Eds.), Advances in Social Theory and Methodology. Towards an integration of micro- and macro-sociologies, London: Routledge and Kegan Paul, 277-303.

Chua, W.F. (1995). Experts, networks and inscriptions in the fabrication of accounting images: A story of the representation of three public hospitals. Accounting, Organizations and Society, 20(2-3), 111-145.

Cooper, D. J., Greenwood, R., Hinings, B. and Brown, J. L. (1998). Globalization and nationalism in a multinational accounting firm: The case of opening new markets in Eastern Europe. Accounting, Organizations and Society, 23(5-6), 531-548.

Czarniawska B. (2004). On Time, Space, and Action Nets. Organization, 11(6), 773-791.

Dambrin, C. and Robson, K. (2011). Tracing performance in the pharmaceutical industry: ambivalence, opacity and the performativity of flawed measures. Accounting, Organizations and Society, 36(7), 428-455. 
de Camara, D. and Renjen, P. (2004). The secrets of successful mergers: dispatches from the front lines. Journal of Business Strategy, 25(3), 10-14.

Durocher, S. and Gendron, Y. (2011). IFRS: On the Docility of Sophisticated Users in Preserving the Ideal of Comparability. European Accounting Review, 20(2), 233-262.

Erb, C. and Pelger, C. (2015) 'Twisting words'? A study of the construction and reconstruction of reliability in financial reporting standard-setting, Accounting, Organizations and Society, 40, 13-40.

Espeland, W. N. and Stevens, M. L. (1998). Commensuration as process. Annual Review of Sociology, 24 313-343.

Espeland, W. N. and Stevens, M. L. (2008). A Sociology of Quantification. European Journal of Sociology / Archives Européennes De Sociologie, 49 (03), 401-436.

Farjaudon, A. and Morales, J. (2013). In search of consensus: The role of accounting in the definition and reproduction of dominant interests. Critical Perspectives on Accounting, 24 (2), 154-171.

Frandsen, A. (2009). From psoriasis to a number and back. Information and Organization, 19, 103128.

Froud, J., Sukhdev, J., Leaver, A. and Williams, K. (2006). Financialization and strategy, Narrative and numbers. London: Routledge.

Gendron, Y. and Bédard, J. (2006). On the constitution of audit committee effectiveness. Accounting, Organizations and Society, 31(3), 211-239.

Gendron, Y., Bédard, J. and Gosselin, M. (2004). Getting inside the black box: a field study of practices in "effective" audit committees. Auditing: A Journal of Practice \& Theory, 23(1), 153171.

Gendron, Y., Cooper, D. J. and Townley, B. (2007). The construction of auditing expertise in measuring government performance. Accounting, Organizations and Society, 32(1-2), 101-129.

Gill, M. (2009). Accountants' truth; Knowledge and ethics in the financial world. Oxford: Oxford University Press. 
Hines, R. D. (1988). Financial accounting: In communicating reality, we construct reality. Accounting, Organizations and Society, 13 (3), 251-261.

Hines, R. D. (1991). The FASB's conceptual framework, financial accounting and the maintenance of the social world. Accounting, Organizations and Society, 16 (4), 313-331.

Hopwood, A. G. (1992). Accounting calculation and the shifting sphere of the economic. European Accounting Review, 1(1), 125-143.

Hopwood, A. G. (2000). Understanding financial accounting practice. Accounting, Organizations and Society, 25(8), 763-766.

Hopwood, A. G. (2006). Accounting calculation and the shifting sphere of the economic. European Accounting Review, 125-143.

Hopwood, A. G. (2009). Exploring the interface between accounting and finance. Accounting, Organizations and Society, 34(5), 549-550.

Jordan, C.E, Clark, S.J. and Vann, C.E. (2007). Using Goodwill Impairment to Effect Earnings Management during SFAS No. 142's Year of Adoption and Later. Journal of Business and Economic Research 5(1), 23-30.

Justesen, L. and Skærbæk, P. (2005). Performance auditing and the production of discomfort. In S. Jönsson and J. Mouritsen (Eds). Northern Lights - Accounting Research in Scandinavia. Malmø: Liber, 321-343.

Kalthoff, H. (2005). Practices of calculation. Theory, Culture \& Society, 22 (2), 69-97.

Kettunen, J. (2014). Interlingual translation of International Financial Reporting Standards: Understanding the problems and procedures of translation. University of Jyvaskyla. Working paper.

Kornberger, M., Justesen, L. and Mouritsen, J. (2011). When you make manager, we put a big mountain in front of you: an ethnography of managers in a Big 4 Accounting firm. Accounting, Organizations and Society, 36(8), 514-533

Lam, T. (2011). A passion for facts. Social surveys and the construction of the Chinese nation-state, 1900-1949. Berkeley: University of California Press. 
Latour, B. (1986). Visualisation and cognition: Thinking with eyes and hand. Knowledge and Society: Studies in the Sociology of Culture and Present, 6, 1-40.

Latour, B. (1987). Science in action; How to follow scientists and engineers through society. Cambridge, Mass: Harvard University Press.

Latour, B. (1989). Clothing the naked truth. In H. Lawson and L. Appignanesi (Eds). Dismantling truth. Reality in the post-modern world. London: Weidenfeld and Nicolson, 101-126.

Latour, B. (2005). Reassembling the Social. Oxford: Oxford University Press.

Laux, C. and Leuz, C. (2009). The crisis of fair-value accounting: Making sense of the recent debate, Accounting, Organizations and Society, 34(6-7), 826-834.

Lezaun, J. (2006). Creating a New Object of Government: Making Genetically Modified Organisms Traceable. Social Studies of Science, 36 (4), 499-531.

Lowe, A. and Koh, B. (2007). Inscribing the organization: Representations in dispute between accounting and production. Critical Perspectives on Accounting, 18(8), 952-974.

Macintosh, N. B. (2006). Commentary: the FASB and accounting for economic reality; accounting truth, lies, or "bullshit"? A philosophical investigation. Accounting and the Public Interest, 6, 2236.

Macintosh, N., B. (2009). Accounting and the truth of earnings reports: philosophical considerations. European Accounting Review, 18(1), 141-175.

Macintosh, N.B., Shearer, T., Thornton, D.B. and Welker, M. (2000). Accounting as simulacrum and hyperreality: perspectives on income and capital. Accounting, Organizations and Society, 25(1), $13-50$.

Massoud, M.F. and Raiborn, C.A. (2003). Accounting for goodwill: are we better off? Review of Business, 24(2), 26-32.

Masters-Stout, B., Costigan, M.L. and Lovata, L.M. 2008. Goodwill impairments and chief executive officer tenure. Critical Perspectives on Accounting 19(8), 1370-1383.

McDonnell, J. (2005). Impairment of assets. Accountancy Ireland, 37(6), 17-19. 
McKernan, J. F. (2007). Objectivity in accounting. Accounting, Organizations and Society, 32(1-2), 155-180.

McGoun, E. G. (1997). Hyperreal finance. Critical Perspectives on Accounting, 8(1-2), 97-122.

Mennicken, A. and Millo, Y. (2012). Testing Values: Financialization and the Emergence of Impairment Rules. Interdisciplinary Perspectives on Accounting Conference, 11-13 July, Cardiff, UK.

Miller, P. (2001). Governing by numbers: why calculative practices matter. Social Research, 68(2), 379-396.

Miller P. and O'Leary T. (1997). Capital budgeting practices and complementarity relations in the transition to modern manufacture. Journal of Accounting Research, 35(2): 257-271.

Miller P. and O'Leary T. (2005a). Capital budgeting, coordination and strategy: A field study of interfirm and intrafirm mechanisms. In Chapman C. S. (Ed.), Controlling strategy: Management Accounting and Performance Measurement. Oxford: Oxford University Press, 151-182.

Miller P. and O'Leary T. (2005b). Managing operational flexibility in investment decisions. Journal of Applied Corporate Finance, 17(2), 18-24.

Miller P. and O'Leary T. (2007). Mediating instruments and making markets: Capital budgeting, science and the economy. Accounting, Organizations and Society, 32(7-8), 701-734.

Miller, P. and Rose, N. (1990). Governing economic life. Economy and Society, 19 (1), 1-31.

Mouritsen, J., Hansen, A. and Hansen, C.Ø. (2009). Short and Long Translations. Management accounting calculations and innovation management. Accounting, Organizations and Society, 34(6/7), 738-754.

Nagel, T. (1986) The view from nowhere. Oxford: Oxford University Press.

Napier, C. and Power, M. (1992). Professional Research, Lobbying and Intangibles: A Review Essay. Accounting and Business Research, 23(89), 85-95.

Nguyen, H. and Kleiner, B.H. (2003). The effective management of mergers. Leadership and Organization Development Journal, 24(8), 447-454. 
Nobes, C. (2013). The continued survival of international differences under IFRS. Accounting and Business Research, 43(2), 83-111.

Nobes, C. and Stadler, C. (2013). How arbitrary are international accounting classifications? Lessons from centuries of classifying in many disciplines, and experiments with IFRS data. Accounting, Organizations and Society, 38(8), 573-595.

Pentland, B.T. (1993). Getting comfortable with the numbers: auditing and the micro-production of macro-order. Accounting, Organizations and Society, 18(7-8), 605-620.

Porter, T.M. (1992). Quantification and the Accounting Ideal in Science. Social Studies of Science, 22, 633-652.

Porter, T.M. (1994a). Making things quantitative. In M. Power (Ed.), Accounting and science. Cambridge: Cambridge University Press.

Porter, T. M. (1994b). Objectivity as standardization: The rhetoric of impersonality in measurement, statistics, and cost-benefit analysis. In A. Megill (Ed). Rethinking objectivity. Duke and London: Duke University Press.

Porter, T.M. (1995). Trust in Numbers: The Pursuit of Objectivity in Science and Public Life. Princeton, New Jersey: Princeton University Press

Power, M. (1992). The politics of brand accounting in the United Kingdom. European Accounting Review, 1(1), 39-68.

Power, M. (1995). Auditing, expertise and the sociology of technique. Critical Perspectives on Accounting, 6(4), 317-339.

Power, M. (1996) 'Making things auditable', Accounting, Organizations and Society, 21 (2-3), 289315.

Power, M. (1997). The Audit Society: Rituals of Verification. Oxford: Oxford University Press.

Power, M. (2003). Auditing and the production of legitimacy. Accounting, Organizations and Society, 28(4), 379-394. 
Power, M. (2010). Fair value accounting, financial economics and the transformation of reliability. Accounting and Business Research, 40(3), 197-210.

Preston, A. M. (2006). Enabling, enacting and maintaining action at a distance: An historical case study of the role of accounts in the reduction of the Navajo herds. Accounting, Organizations and Society, 31(6), 559-578.

Qu, S.Q. and Cooper, D.J. (2011). The role of inscriptions in producing a balanced scorecard. Accounting, Organizations and Society, 36(6), 344-362.

Quagli, A. (2011). Goodwill accounting as missing link between financial accounting and management accounting: Literature review and research agenda. Financial Reporting, 17-39.

Quattrone, P. and Hopper, T. (2001). What does organisational change mean? Speculations on a taken for granted category. Management Accounting Research, 12(4), 403-435.

Quattrone, P. and Hopper, T. (2005). A 'time-space odyssey': management control systems in two multinational organisations. Accounting, Organizations and Society, 30(7-8), 735-764.

Ramanna, K. (2008). The Implications of Unverifiable Fair-Value Accounting: Evidence from the Political Economy of Goodwill Accounting. Journal of Accounting and Economics, 45(2-3), 253281.

Ramanna, K. and Watts, R.L. (2012). Evidence on the Use of Unverifiable Estimates in Required Goodwill Impairment. Review of Accounting Studies, 17(4), 749-780.

Robson, K. (1991). On the arenas of accounting change: The process of translation. Accounting, Organizations and Society, 16(5-6), 547-570.

Robson, K. (1992). Accounting numbers as 'inscription': Action at a distance and the development of accounting. Accounting, Organizations and Society, 17(7), 685-708.

Robson, K. (1994). Inflation accounting and action at a distance: The sandilands episode. Accounting, Organizations and Society, 19(1), 45-82.

Robson, K. and Young, J. J. (2009). Socio-political studies of financial reporting and standard setting. In C. S. Chapman, D. J. Cooper and P. B. Miller (Eds.). Accounting, organizations and institutions. essays in honour of Anthony Hopwood. Oxford: Oxford University Press, 341-366. 
Rose, N. and Miller, P. B. (2008). Governing the present. Administering economic, social and personal life. Cambridge: Cambridge University Press.

Rottenburg, R. (2009). Far-Fetched Facts: A Parable of Development Aid. Cambridge, MA, USA: MIT Press.

Scott, J. C. (1998) Seeing like a state, how certain schemes to improve the human condition have failed. New Haven, USA: ebrary, Inc.

Sherwood, K. (1990). An Auditor's Approach to Brands. In M. Power (Ed.), Brand and Goodwill Accounting Strategies. Cambridge: Woodhead-Faulkner, 78-86.

Smith-Lacroix, J., Durocher, S, and Gendron, Y. (2012). The erosion of jurisdiction: Auditing in a market value accounting regime. Critical Perspectives on Accounting 23(1): 36-53.

Suddaby, R., Cooper, D. J. and Greenwood, R. (2007). Transnational regulation of professional services: Governance dynamics of field level organizational change. Accounting, Organizations and Society, 32(4-5), 333-362.

Suddaby, R., Gendron, Y. and Lam, H. (2009). The organizational context of professionalism in accounting, Accounting, Organizations and Society, 34 (3-4), 409-427.

Thompson, G. (1987). Inflation accounting in a theory of calculation. Accounting, Organizations and Society, 12 (5), 523-543.

Vollmer, H. (2003). Bookkeeping, accounting, calculative practice: the sociological suspense of calculation. Critical Perspectives on Accounting, 14 (3), 353-381.

Vollmer, H. (2007). How to do more with numbers: Elementary stakes, framing, keying, and the threedimensional character of numerical signs. Accounting, Organizations and Society, 32 (6), 577-600.

Vollmer, H., Mennicken, A. and Preda, A. (2009). Tracking the numbers: Across accounting and finance, organizations and markets. Accounting, Organizations and Society, 34(5), 619-637.

Weißenberger, B. E. and Angelkort, H. (2011). Integration of financial and management accounting systems: The mediating influence of a consistent financial language on controllership effectiveness. Management Accounting Research, 22(3), 160-180. 
Whittington, G. (2008). Fair value and the IASB/FASB conceptual framework project: an alternative view. Abacus, 44(2), 139-168.

Wines, G., Dagwell, R. and Windsor C. (2007). Implications of the IFRS goodwill accounting treatment. Managerial Auditing Journal, 22(9), 862-880.

Young, J. J. (2006). Making up users. Accounting, Organizations and Society, 31(6), 579-600.

\begin{tabular}{|c|c|c|c|c|c|c|c|}
\hline \multicolumn{4}{|c|}{ Summary of Goodwill impairment testing results } & & \multicolumn{2}{|c|}{ Testing date 30.9 .2010} & \\
\hline & & & & & & & \\
\hline & & & \multicolumn{3}{|c|}{ Forecast period 2010-2014 } & Break-even & Sales info \\
\hline \multirow[t]{2}{*}{ CGU } & WACC & Pre-tax & EV & Net assets & Results & EBIT change & Compound \\
\hline & $\%$ & discount rate $\%$ & $€ M$ & $€ M$ & & threshold \% & growth rate $\%$ \\
\hline CGU A & 8,87 & 15,67 & 860 & 355 & Not impaired & $-10,0$ & 5,0 \\
\hline CGU B & 8,87 & 15,94 & 240 & 200 & Not impaired & $-2,0$ & $-2,3$ \\
\hline CGU C & 9,09 & 14,95 & 175 & 143 & Not impaired & 2,5 & 1,2 \\
\hline CGU D & 9,22 & 15,20 & 354 & 110 & Not impaired & $-25,0$ & 2,6 \\
\hline CGUE & 8,87 & 13,90 & 78 & 55 & Not impaired & 11,0 & 3,2 \\
\hline CGU F & 8,76 & 14,26 & 331 & 170 & Not impaired & $-6,5$ & 4,1 \\
\hline CGU G & 8,76 & 11,90 & 155 & 33 & Not impaired & 5,0 & 9,6 \\
\hline CGU H & 8,76 & 14,10 & 30 & 10 & Not impaired & 3,0 & 3,8 \\
\hline \multirow[t]{2}{*}{ Headoffice } & 8,87 & N/A & -132 & $\mathrm{~N} / \mathrm{A}$ & N/A & $\mathrm{N} / \mathrm{A}$ & N/A \\
\hline & & Total EV & 2091 & & & & \\
\hline \multicolumn{8}{|c|}{\begin{tabular}{|l|l|l|l|} 
Cash flow based on the latest updated forecast for 2010 & & \\
\end{tabular}} \\
\hline \multicolumn{8}{|c|}{ Each CGU (segment) has provided data for 2011 - 2013 (based on the strategy review by management in 09/2010) } \\
\hline \multicolumn{8}{|c|}{ 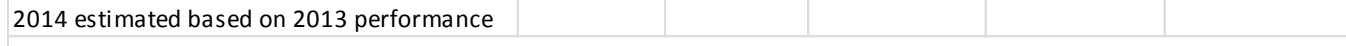 } \\
\hline \multicolumn{8}{|c|}{ When WACC applied in discounting, cash flows are post-tax-Pre-tax discount rate also iterated for IFRS purposes } \\
\hline \multicolumn{8}{|c|}{ Net Assets of CGUs as of 30.9 .2010} \\
\hline \multicolumn{8}{|c|}{ Terminal growth rate $1,8 \%$} \\
\hline \multicolumn{8}{|c|}{ When EV (Enterprise value) > net assets, there is no need for impairment } \\
\hline \multicolumn{8}{|c|}{\begin{tabular}{|l|l|l|l|l|} 
CONCLUSION: No impairment detected & & & \\
\end{tabular}} \\
\hline \multicolumn{8}{|c|}{ Break-even analysis calculates yearly EBIT change from 2010 t0 2014 required to reach break even position (EV = Net assets } \\
\hline \multicolumn{7}{|c|}{ (When the EBIT level is negative in 2010, the required annual EBIT change cannot be calculated) } & \\
\hline \multicolumn{8}{|c|}{ Compound growth rate of Net sales from 2010 to 2013 as forecasted by the CGU (Segment) and 2014 estimated } \\
\hline
\end{tabular}

Figure 1: Example of a template for reporting goodwill impartment tests used in a firm (actual numbers are disguised). 
APPENDIX 1: Interviews

\begin{tabular}{|c|c|c|}
\hline Actor group & $\begin{array}{l}\text { First round } \\
\text { Duration in } \\
\text { minutes }\end{array}$ & $\begin{array}{l}\text { Second round } \\
\text { Duration in } \\
\text { minutes }\end{array}$ \\
\hline \multicolumn{3}{|l|}{ Academics: } \\
\hline 1. Professor A, University 1 & 60 & \\
\hline $\begin{array}{l}\text { 2. Professor B, University } 1 \text {, A Chairman of the } \\
\text { Board }\end{array}$ & 65 & \\
\hline 3. Professor (Adjunct) C, University 1 & 60 & \\
\hline 4. Professor, University 2 & 30 & \\
\hline 5. Professor, University 3 & 40 & \\
\hline 6. Professor, University 4 & 40 & \\
\hline \multicolumn{3}{|l|}{ Auditors (Big-4): } \\
\hline 1. Partner, auditor; Audit firm 1 & 90 & $93+70$ \\
\hline 2. Partner, auditor; Audit firm 2 & 77 & \\
\hline 3. Partner, auditor; Audit firm 3 & 51 & \\
\hline 4. Partner, auditor; Audit firm 4 & 80 & \\
\hline \multicolumn{3}{|l|}{ Financial Supervisory Authority: } \\
\hline 1. Head of division, Financial reporting & 120 & \\
\hline 2. IFRS expert A, Financial reporting & 110 & \multirow[t]{2}{*}{92} \\
\hline 3. IFRS expert B, Financial reporting & 87 & \\
\hline \multicolumn{3}{|l|}{ Companies: } \\
\hline 1. Senior Vice President, Finance, Firm 1 & 65 & $14^{*}$ \\
\hline 2. Executive Vice President, CFO, Firm 2 & 46 & \\
\hline 3. Executive Vice President, Firm 3 & 56 & \\
\hline $\begin{array}{l}\text { 4. Senior Vice President, Financial Control, Firm } \\
4\end{array}$ & \multirow[t]{2}{*}{80} & \\
\hline 5. Financial standard adviser, Firm 4 & & $17 *$ \\
\hline
\end{tabular}




\begin{tabular}{|c|c|c|}
\hline 6. CFO, Firm 5 & 53 & \\
\hline 7. CFO, Firm 6 & 100 & \\
\hline 8. CFO, Firm 7 & 50 & \\
\hline 9. CFO, Firm 8 & 55 & \\
\hline 10. CFO, Firm 9 & 60 & \\
\hline 11. CFO, Firm 10 & 90 & \\
\hline 12. CFO, Firm 11 & 36 & \\
\hline $\begin{array}{l}\text { 13. Director, Group Accounting and Taxation, } \\
\text { Firm } 12\end{array}$ & 74 & \\
\hline 14. Group Financial Controller, Firm 12 & & \\
\hline Financial analysts and Investors: & & \\
\hline 1. Senior Equity Analyst, Analyst 1 & 57 & $10^{*}$ \\
\hline 2. Head of Strategies, Analyst 2 & 52 & $13^{*}$ \\
\hline 3. Portfolio Manager, Investor 1 & 114 & $11^{*}$ \\
\hline 4. Portfolio Manager, Equities, Investor 2 & 40 & $10^{*}$ \\
\hline 5. Managing Director, Investor 3 & 34 & \\
\hline 6. Senior Analyst, Analyst 3 & 61 & $16^{*}$ \\
\hline 7. Head of Equities, Direct Equities, Investor 4 & 52 & $11^{*}$ \\
\hline 8. Chief Executive Officer, Investor 5 & 35 & \\
\hline 9. Deputy Chief Investment Officer, Investor 6 & 44 & $10^{*}$ \\
\hline 10. Analyst (Equity Research), Analyst 4 & 69 & $12 *$ \\
\hline 11. Equity Analyst, Analyst 5 & 37 & \\
\hline 12. Analyst, Analyst 6 & 68 & \\
\hline 13. Managing Director, Investor 7 & 34 & \\
\hline 14. Analyst, Analyst 7 & 47 & \\
\hline $\begin{array}{l}\text { 15. Head of Trading and Capital Markets, Analyst } \\
8\end{array}$ & 34 & \\
\hline 16. Equity Analyst, Analyst 9 & 63 & \\
\hline \multicolumn{3}{|l|}{ Media: } \\
\hline 1. Journalist, Magazine 1 & 60 & \\
\hline 2. Journalist, Magazine 2 & 54 & \\
\hline
\end{tabular}




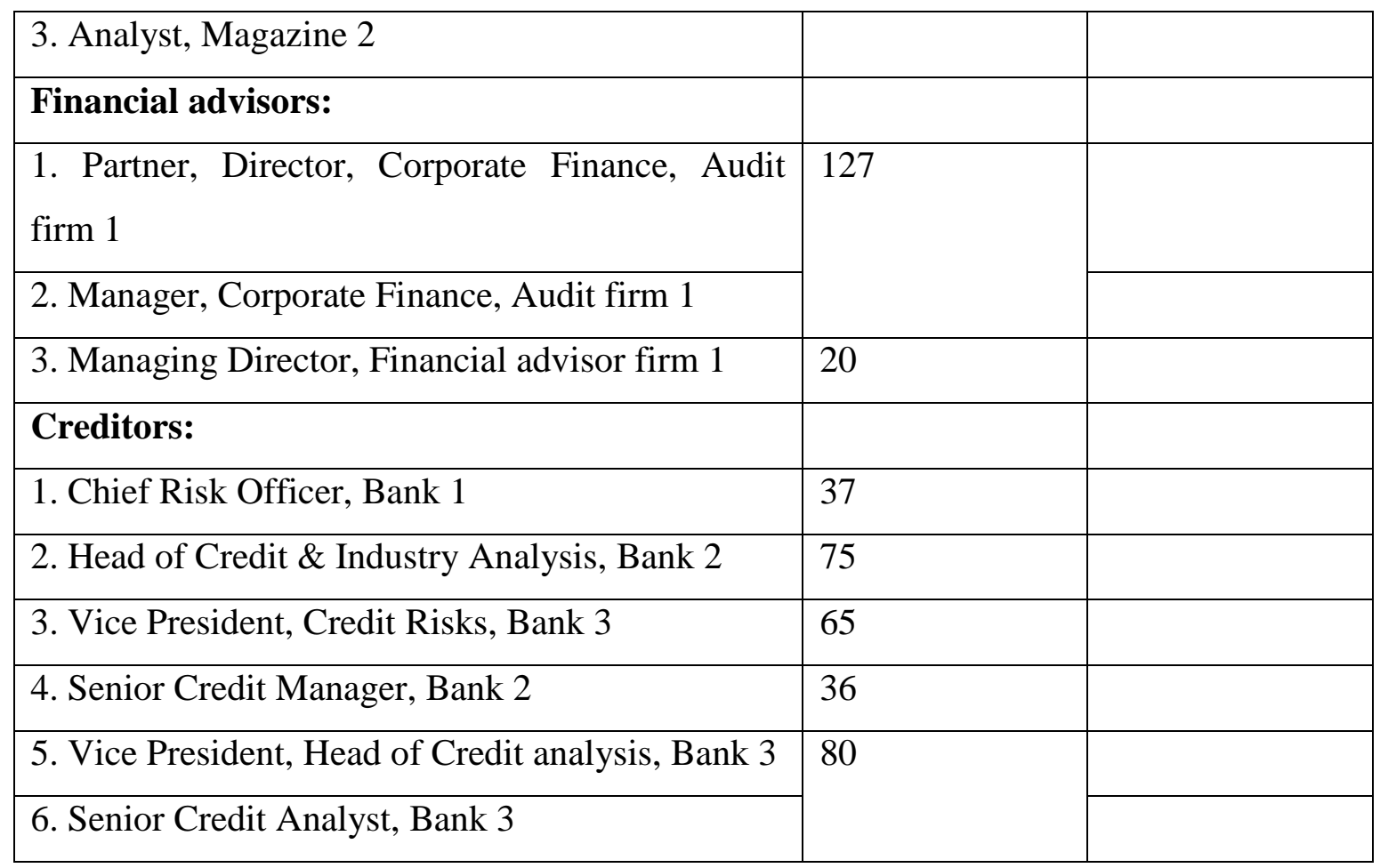

The interview data comprises 53 semi-structured interviews with 55 interviewees and 10 follow-up (telephone) conversations (marked by asterisks) (57 hours in total).

APPENDIX 2: Summarised interview structure (case-specific for the actor groups)

Interviewee and goodwill impairment testing: the role and opinions

- What is your general opinion about the (goodwill) impairment testing standard (IAS36)?

- What is your involvement with goodwill impairment testing?

- When does goodwill matter?

- How does goodwill matter?

- What are the benefits of goodwill impairment testing for different actor groups?

- What does recognition of an impairment loss signal?

- Have attitudes towards goodwill and goodwill amortization changed: now vs. the pre-IFRS era? 
- How do your colleagues perceive goodwill impairment testing?

- Are you interested in goodwill and goodwill impairment testing?

- Is the information obtained in goodwill impairment testing useful?

- Is the information reported about goodwill impairment testing understandable?

- Are analysts/investors interested in your goodwill (for firms)?

- Can the measurement of intangible assets be reliable?

- Do goodwill and recognition of an impairment loss have an impact on company valuation?

- Does goodwill and a recognition of an impairment loss have an impact on managerial behaviour?

- How could the standards or procedures related to goodwill be improved?

\section{Challenges in goodwill impairment testing}

- What are the challenges in goodwill impairment testing?

- How could a company hide a need to recognise an impairment loss?

- What are the factors diminishing the potential for hiding a need for a recognition of an impairment loss

- Why would hiding/delaying recognition of an impairment loss be advantageous to companies/managers?

- Should there be more recognition of impairment losses during a recession/depression?

\section{Descriptions: processes and procedures related to goodwill impairment testing}

- Goodwill impairment testing process in companies

- Auditing of goodwill impairment testing

- Role of financial supervisory authorities

- Company valuation process 